\title{
A Note On The Partition Dimension of Thorn of Fan Graph
}

\author{
Auli Mardhaningsih \\ Andalas University, aulimardhaningsih@gmail.com \\ doi: https://doi.org/10.15642/mantik.2019.5.1.45-49
}

\begin{abstract}
Abstrak: Misalkan $\mathrm{G}$ adalah suatu graf terhubung.Himpunan titikV(G) di partisi menjadi k buah partisi $S_{1}, S_{2}, \ldots, S_{k}$ yang saling lepas. Notasikan $\Pi=\left\{S_{1}, S_{2}, \ldots, S_{k}\right\}$.Maka representasi $v \in V(G)$ terhadap phi didefenisikan : $\mathrm{r}(\mathrm{v} \mid \Pi)=\left(\mathrm{d}\left(\mathrm{v}, \mathrm{S}_{1}\right), \mathrm{d}\left(\mathrm{v}, \mathrm{S}_{2}\right), \ldots, \mathrm{d}\left(\mathrm{v}, \mathrm{S}_{\mathrm{k}}\right)\right)$, Jika untuk setiap dua titik yang berbeda $u, v \in \mathrm{V}(\mathrm{G})$ berlaku $\mathrm{r}(\mathrm{u} \mid \Pi)=\mathrm{r}(\mathrm{v} \mid \Pi)$, maka $\Pi$ dikatakan partisi penyelesaian dari graf $\mathrm{G}$. Graf kipas diperoleh dari operasi graf hasil tambah $\mathrm{K}_{1}+\mathrm{P}_{\mathrm{n}}$. Graf kipas dinotasikan dengan $F_{1, n}$ untuk $\mathrm{n} \geq 2$. Graf thorn untuk graf kipas diperoleh dengan cara menambahkan daun sebanyak $l_{\mathrm{i}}$ kesetiap titik di graf kipas, dinotasikan dengan $\operatorname{Th}\left(F_{1, n}, l_{1}, l_{2}, \ldots, l_{n+1}\right)$. Pada tulisan ini, akan dibahas tentang dimensi partisi graf thorn dari graf kipas $F_{1, n} u n t u k n=2,3,4$.
\end{abstract}

Kata kunci: Partisi penyelesaian, dimensi partisi, graf kipas, graf thorn

\begin{abstract}
Let $G=(V, E)$ be a connected graph and $S \subseteq V(G)$. For a vertex $v \in V(G)$ and an ordered $k$-partition $\Pi=\left\{S_{1}, S_{2}, \ldots, S_{k}\right\}$ of $V(G)$, the presentation of $v$ concerning $\Pi$ is the $k$-vector $r(v \mid \Pi)=\left(d\left(v, S_{1}\right), d\left(v, S_{2}\right), \ldots, d\left(v, S_{k}\right)\right)$, where $d\left(v, S_{i}\right)$ denotes the distance between $v$ and $S_{i}$ for $i \in\{1,2, \ldots, n\}$. The $k$-partition $\Pi$ is said to be resolving if for every two vertices $u, v \in V(G)$, the representation $r(u \mid \Pi) \neq r(v \mid \Pi)$. The minimum $k$ for which there is a resolving $k$-partition of $V(G)$ is called the partition dimension of $G$, denoted by $p d(G)$. Let $V(G)=\left\{x_{1}, x_{2}, \ldots, x_{n}\right\}$. Let $l_{1}, l_{2}, \ldots, l_{n}$ be non-negative integer, $l_{i} \geq 1$,for $i \in\{1,2, \ldots, n\}$. The thorn of $G$, with parameters $l_{1}, l_{2}, \ldots, l_{n}$ is obtained by attaching $l_{i}$ vertices of degree one to the vertex $x_{i}$, denoted by $\operatorname{Th}\left(G, l_{1}, l_{2}, \ldots, l_{n}\right)$. In this paper, we determine the partition dimension of $\operatorname{Th}\left(G, l_{1}, l_{2}, \ldots, l_{n}\right)$ where $G \simeq F_{1, n}$, the fan on $\mathrm{n}+1$ vertices, for $n=2,3,4$.
\end{abstract}

Keywords: Resolving partition, partition dimension, fan, thorn graph 


\section{Introduction}

Let $G=(V, E)$ be an arbitrary connected graph. [1] defined the partition dimension as follows. Let $u$ and $v$ be two vertices in $V(G)$. The distance $d(u, v)$ is the length of the shortest path between $u$ and $v$ in $G$. For an ordered set $\Pi=\left\{S_{1}, S_{2}, \ldots, S_{k}\right\}$ of vertices in a connected graph $G$ and a vertex $v$ of $G$, the $k$-vector $r(v \mid \Pi)=$ $\left(d\left(v, S_{1}\right), d\left(v, S_{2}\right), \ldots, d\left(v, S_{k}\right)\right)$, is the presentation of $v$ with respect to $\Pi$. The minimum $k$ for which there is a resolving $k$-partition of $V(G)$ is called the partition dimension of $G$, denoted by $p d(G)$. All notation in graph theory needed in this paper refers to [2].

Stated the following theorem.

Theorem 1.1. [2] Let $G$ be a connected graph on $n$ vertices, $n \geq 2$. Then $p d(G)=2$ if and only if $G \simeq P_{n}$.

In the same paper, Chartrand et al. [2] also gave the necessary condition in partitioning the set of vertices as follows.

Lemma 1.2. [2] Suppose that $\Pi$ is the resolving partition of $V(G)$ and $u, v \in V(G)$. If $d(u, w)=d(v, w)$ for every vertex $w \in V(G) \backslash\{u, v\}$ then $u$ and $v$ belong to a different class of $\Pi$.

\section{Main Results}

The fan $F_{1, n}$ on $n+1$ vertices is defined as the graph constructed by joining $K_{1}$ and $P_{n}$, denoted by $K_{1}+P_{n}$ where $K_{1}$ is the complete graph on 1 vertex and $P_{n}$ Is a path on $n$ vertices, for $n \geq 2$. The vertex set and edge set of $F_{1, n}$ are as follows.

$$
\begin{aligned}
& V\left(F_{1, n}\right)=\left\{x_{i} \mid 1 \leq i \leq n+1\right\} \\
& E\left(F_{1, n}\right)=\left\{x_{1} x_{t} \mid 1 \leq t \leq n\right\} \cup\left\{x_{s} x_{s+1} \mid 1 \leq s \leq n-1\right\}
\end{aligned}
$$

$l_{1}, l_{2}, \ldots, l_{n+1} \mathrm{Be}$ some positive integer. The thorn graph of $F_{1, n}$ is obtained by adding $l_{i}$ leaves to vertex $x_{i}$, for $1 \leq i \leq n+1$, denoted by $\operatorname{Th}\left(F_{1, n}, l_{1}, l_{2}, \ldots, l_{n+1}\right)$. The construction of thorn graph is taken from [3]. The vertex set and edge set of $H \simeq$ $\operatorname{Th}\left(F_{1, n}, l_{1}, l_{2}, \ldots, l_{n+1}\right)$ are as follows.

$$
\begin{aligned}
& V(H)=\left\{x_{i} \mid 1 \leq i \leq n+1\right\} \cup\left\{x_{i j} \mid 1 \leq i \leq n+1,1 \leq j \leq l_{i}\right\}, \text { and } \\
& E(H)=\left\{x_{1} x_{t} \mid 1 \leq t \leq n\right\} \cup\left\{x_{s} x_{s+1} \mid 1 \leq s \leq n-1\right\} \cup \\
& \left\{x_{i} x_{i j} \mid 1 \leq i \leq n, 1 \leq j \leq n\right\} .
\end{aligned}
$$

In Theorem 2.1 we determine the partition dimension of $\operatorname{Th}\left(F_{1,2}, l_{1}, l_{2}, l_{3}\right)$ for $l_{i} \geq 1$, $i \in 1,2,3$.

Theorem 2.1. Let $\operatorname{Th}\left(F_{1,2}, l_{1}, l_{2}, l_{3}\right)$ be thorn of fan $F_{1,2}$ with $l_{i} \geq 1, i \in 1,2,3$. Denote $l_{\max }=\max \left\{l_{1}, l_{2}, l_{3}\right\}$.

The partition dimension of $\operatorname{Th}\left(F_{1,2}, l_{1}, l_{2}, l_{3}\right)$ is

$$
\operatorname{pd}\left(\operatorname{Th}\left(F_{1,2}, l_{1}, l_{2}, l_{3}\right)\right)=\left\{\begin{array}{c}
3, \text { for } l_{\max }=1,2 \text { or } 3 \\
l_{\max }, \quad \text { for } l_{\max } \geq 4
\end{array}\right.
$$




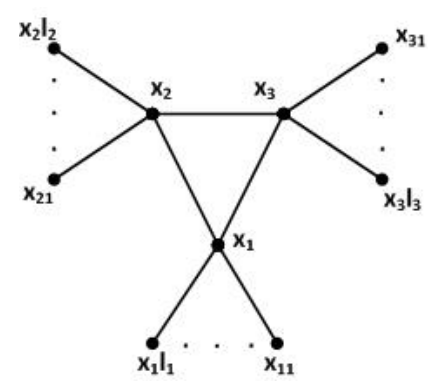

Figure 1. $\operatorname{Th}\left(F_{1,2}, l_{1}, l_{2}, l_{3}\right)$

Proof. The proof is divided into two cases.

Case 1. $1 \leq l_{\max } \leq 3$.

Let $H_{1} \simeq \operatorname{Th}\left(F_{1,2}, l_{1}, l_{2}, l_{3}\right)$, with $1 \leq l_{\max } \leq 3$. Because $H_{1} \neq P_{n}$ then from Theorem 1.1 , it is obtained that $p d\left(H_{1}\right) \geq 3$. Next, it will be shown that $p d\left(H_{1}\right) \leq 3$ by constructing three ordered partitions. Note that from Lemma 1.2, every leaf at the vertex $x_{i}$ Must be on a different partition. Therefore, we define $\Pi=\left\{S_{1}, S_{2}, S_{3}\right\}$, where $S_{i}=\left\{x_{i}, x_{k i} \mid 1 \leq i \leq 3,1 \leq k \leq 3\right\}$,

Because of $d\left(v, S_{i}\right)=0$ while $d\left(u, S_{i}\right) \neq 0$ for $v \in S_{i}$ and $u \notin S_{i}$, it is clear that every two vertices in different partitions have different representations. Therefore, it is sufficient to check the representations of two vertices in the same partition. Because of $d\left(x_{k i}, S_{j}\right)=d\left(x_{i}, S_{j}\right)+1$ for $i \neq j, 1 \leq i, j \leq 3$, then $r\left(x_{k i} \mid \Pi\right) \neq r\left(x_{i} \mid \Pi\right)$. Thus, we have that $p d\left(H_{1}\right) \leq 3$.

Case 2. $l_{\max } \geq 4$.

Let $H_{2} \simeq \operatorname{Th}\left(F_{1,2}, l_{1}, l_{2}, l_{3}\right)$, with $l_{\max } \geq 4$. Let $l_{\max }=m$ and suppose that $p d\left(H_{2}\right)=$ $m-1$. Then we have $\Pi=\left\{S_{1}, S_{2}, \ldots, S_{m-1}\right\}$. Thus there are at least two vertices, namely $x_{1 p}$ and $x_{1 q}$, in the same partition, for $1 \leq p, q \leq m$. But from Lemma 1.2, $x_{1 p}$ and $x_{1 q}$ Must be placed in different partitions. Therefore, $|\Pi| \geq m$, a contradiction.

Next, we construct $\Pi=\left\{S_{1}, S_{2}, \ldots, S_{m}\right\}$, where $S_{i}=\left\{x_{i}, x_{k i} \mid 1 \leq i \leq 3,1 \leq k \leq 3\right\}$,

$S_{j}=\left\{x_{k j} \mid 1 \leq k \leq 3,4 \leq j \leq l_{\max }\right\}$,

Because of $d\left(x_{k i}, S_{j}\right)=d\left(x_{i}, S_{j}\right)+1$ for $i \neq j, 1 \leq i, j \leq l_{\text {max }}$, then $r\left(x_{k i} \mid \Pi\right) \neq$ $r\left(x_{i} \mid \Pi\right)$. Next, because of $d\left(x_{k i}, S_{j}\right) \neq d\left(x_{l i}, S_{j}\right)+1$ for $k \neq l, 1 \leq k, l \leq l_{\max }$, it is clear that $r\left(x_{k i} \mid \Pi\right) \neq r\left(x_{l i} \mid \Pi\right)$. Therefore, we have $p d\left(H_{2}\right) \leq l_{\max }$.

In Theorem 2.2 we determine the partition dimension of $\operatorname{Th}\left(F_{1,3}, l_{1}, l_{2}, l_{3}, l_{4}\right)$ for $l_{i} \geq$ $1, i \in 1,2,3,4$.

Theorem 2.2. Let $\operatorname{Th}\left(F_{1,3}, l_{1}, l_{2}, l_{3}, l_{4}\right)$ be a thorn of fan $F_{1,3}$ with $l_{i} \geq 1, i \in 1,2,3,4$. Denote $l_{\text {max }}=\max \left\{l_{1}, l_{2}, l_{3}, l_{4}\right\}$. Let $x_{l_{i}}$ be the vertex in $F_{1,3}$ with $l_{i}$ leaves, and $\left|x_{\text {lmax }}\right|$ be the number of vertices with $l_{\max }$ Leaves. The partition dimension of $\operatorname{Th}\left(F_{1,3}, l_{1}, l_{2}, l_{3}, l_{4}\right)$ is 


$$
\operatorname{pd}\left(\operatorname{Th}\left(F_{1,3}, l_{1}, l_{2}, l_{3}, l_{4}\right)\right)=\left\{\begin{array}{l}
3, \text { for } l_{\max }=1 \text { or } 2, \\
\quad \text { and } \text { for } l_{\max }=3, \text { if }\left|x_{\text {lmax }}\right|=1 \text { or } 2, \\
4, \text { for } l_{\max }=3, \text { if }\left|x_{\text {lmax }}\right|=3 \text { or } 4, \\
l_{\max }, \text { for } l_{\max } \geq 4 .
\end{array}\right.
$$

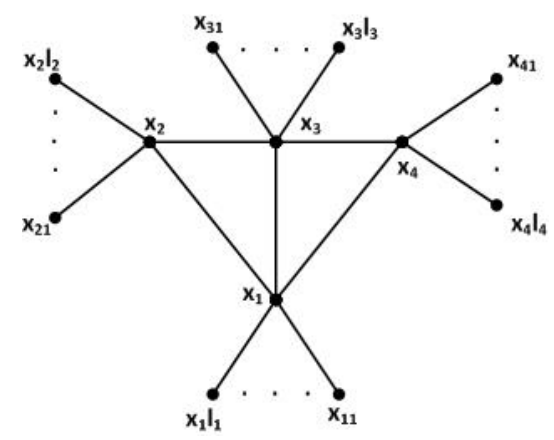

Figure2. $\operatorname{Th}\left(F_{1,3}, l_{1}, l_{2}, l_{3}, l_{4}\right)$

Proof. The proof is similar to the proof of Theorem 2.1

In Theorem 2.3 we determine the partition dimension of $\operatorname{Th}\left(F_{1,4}, l_{1}, l_{2}, l_{3}, l_{4}, l_{5}\right)$ for $l_{i} \geq 1, i \in 1,2,3,4,5$.

Theorem 2.3. Let $\operatorname{Th}\left(F_{1,4}, l_{1}, l_{2}, l_{3}, l_{4}, l_{5}\right)$ be a thorn of fan $F_{1,4}$ with $l_{i} \geq 1, i \in 1,2,3,4,5$. Denote $l_{\max }=\max \left\{l_{1}, l_{2}, l_{3}, l_{4}, l_{5}\right\}$. Let $x_{l_{i}}$ be the vertex in $F_{1,4}$ with $l_{i}$ leaves, and $\left|x_{\text {lmax }}\right|$ be the number of vertices with $l_{\max }$ Leaves. The partition dimension of $\operatorname{Th}\left(F_{1,3}, l_{1}, l_{2}, l_{3}, l_{4}, l_{5}\right)$ is

$$
\operatorname{pd}\left(\operatorname{Th}\left(F_{1,4}, l_{1}, l_{2}, l_{3}, l_{4}, l_{5}\right)\right)=\left\{\begin{array}{l}
3, \text { for } l_{\max }=1, \\
\text { and } \text { for } l_{\max }=2, \text { if }\left|x_{l \max }\right|=1 \text { or } 2, \\
\text { and } \text { for } l_{\max }=3, \text { if }\left|x_{l \max }\right|=1, \\
4, \text { for } l_{\max }=2, \text { if }\left|x_{l \max }\right|=3,4 \text { or } 5, \\
\text { and for } l_{\max }=3, \text { if }\left|x_{l \max }\right|=2,3,4 \text { or } 5, \\
\text { and } \text { for } l_{\max }=4, \text { if }\left|x_{l \max }\right|=1,2,3 \text { or } 4, \\
5, \text { for } l_{\max }=4, \text { if }\left|x_{l \max }\right|=5, \\
l_{\max }, \text { for } l_{\max } \geq 5
\end{array}\right.
$$




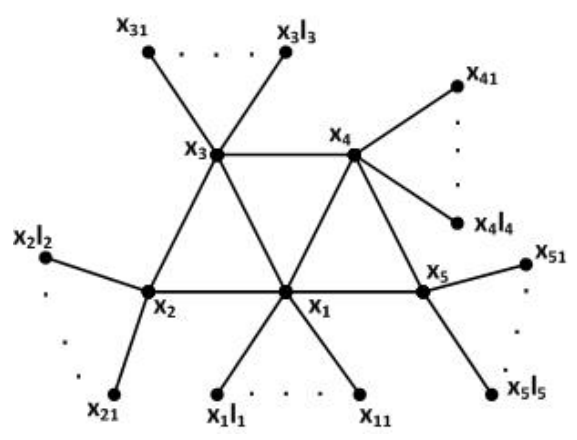

Figure 3. $\operatorname{Th}\left(F_{1,4}, l_{1}, l_{2}, l_{3}, l_{4}, l_{5}\right)$

Proof. The proof is similar to the proof of Theorem 2.1 and Theorem 2.2.

\section{References}

[1] G. Chartrand, S. E and Z. P, "The Partition dimension of a graph," Aequationes Math, pp. 45-54, 2000.

[2] J. A. Bondy and U. Murty, Graph Theory with Applications, London, 1976.

[3] A. "Partition dimension of amalgamation," Bulletin of Mathematics, pp. 161-167, 2012.

[4] A. Kirlangic, "The Scattering number of thorn graph," International Journal of computer math, pp. 299-311, 2004.

[5] E. Baskoro and D. , "The partition dimension of corona product of two graph," Far East J. Math. Sci, pp. 181-196, 2012.

[6] N. L. Biggs, R. Lloyd and R. Wilson, Graph theory, Oxford: 1736-1936, 1986.

[7] G. Chartrand and S. E, "On partition dimension of a graph," Congr. numer, pp. 157168, 1998.

[8] E. Rahimah, L. Yulianti and D. Welyyanti, "Penentuan bilangan kromatik lokasi graf thorn dari graf roda," jurnal matematika unand, 2018.

[9] J. Gross and J. Yellen, Graph theory and its applications (Second Edition), New York, 2006.

[10] I. Gutman, "Distance in Thorny Graph," Publ.Ins.Math, pp. 31-36, 1998.

[11] D. O. Haryeni, E. T. Baskoro, and S. W. Saputro, "On the partition dimension of disconnected graphs," 2017.

[12] A. Juan, V. Rodriguez and L. Magdalena, "On the partition dimension of trees," discrete applied mathematics, pp. 204-209, 2014.

[13] E. Lloyd, J. Bondy and U. Murt, "Graph theory with apllication," the mathematical gazette, pp. 62-63, 2007.

[14] R. Munir, Matematika Diskrit, Bandung, 2003.

[15] I. Tomescu, I. Javaid and S. , "On the Partition Dimension and Conected Partition dimension of wheels," Ars Combinatoria, pp. 311-317, 2007.

[16] I. Tomescu, "Discrepancies between metric dimension of a connected graph," Discrete Math, pp. 5026-5031, 2008. 